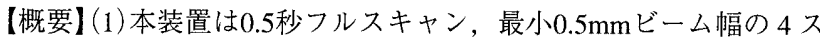
ライスマルチスライスCTである。(2)検出器素子の体軸方向長さを 不等ピッチ 8 列とすることで, 6 種類のビーム幅を確保しつつ, 検 出器素子間のギャップ数を減らしX線利用効率を向上している．本 方式は, 検出器回路を簡易化でき信頼性向上に寄与する。(3)検出器 側のコリメータと検出器の間に特殊な構造をしたコリメータを挿入 することで，検出器に入射する散乱線をカットし， $24 \mathrm{l} / \mathrm{cm}$ の空間分 解能を達成した。（4)X線管球側のコリメー夕は，X線管球アノード の熱膨張によるX線ビームの体軸方向のずれを検出しこれを補正す る機構をもち, 被曝を増加させることなく正確な複数断面デー夕を 收集し画質劣化を補正できる，(5)ヘリカルスキャンピッチは $1 \sim 8$ まで選択でき，全身スクリーニング検査に有効である。(6) $\mathrm{mAs}$ 制御 方式を採用し，SD值を気にすることなくピッチを選択できる。 (7) マルチスライスCTに最適化された操作画面により，撮像から フィルミングまでの操作性を向上し，術者の負担を軽減している.

(8)血管狭窄度判定，冠動脈内の石灰化の程度を評価，脳血流解析な ど各種診断においても有用なアプリケーションを持っている。（9） シェア世界一の放射線治療計画用ソフトウェア搭載ワークステー ションACQSIM, フラットパネル検出器搭載透視装置, 穿刺ナビ ゲーションシステムとの組合せにより，治療領域への応用も可能で ある。

【結論】本装置は高速マルチスライスCTの利点を生かすための豊富な アプリケーションを持ち, 循環器領域をはじめとする各領域の診 断，さらに治療にも有用なシステムである。

144 新型X線CT装置Asteionマルチスライスシステムの開発 (株) 東芝医用システム社 · 那須工場 · 医用機器第二技術部 立崎 寿 【目的】撮影時間の大幅な短縮と体軸方向分解能の向上を同時に実現 することを目的とし，1 スキャン 0.75 秒の高速スキャンが可能な Asteion $^{\mathrm{TM}}$ をべースとしたAsteion ${ }^{\mathrm{TM}}$ マルチスライスCTシステムを開発 した。ここでは，その要素技術と臨床的特長について報告する。

【方法】4列同時収集が可能であり，かつ最小スライス厚 $0.5 \mathrm{~mm} \times 4$ 列 のマルチスライス検出器/高速デー夕収集装置, 多点補間法を特徵と する新再構成(MUSCOT再構成)アルゴリズム, 超高速画像再構成シ ステムを，コンパクトでありながら高冷却効率X線管球Helicool ${ }^{\mathrm{TM}}$ を

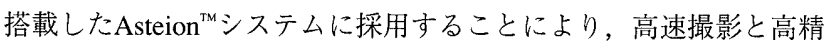
度撮影を両立したAsteion ${ }^{\mathrm{TM}}$ マルチスライスシステムを実現した。

【結果】1)高速撮影：シングルシステムに対し，同スライス厚では撮 影時間が最大 $1 / 6$ に短縮. 患者拘束時間の短縮により，患者負担が大 幅に軽減できた。 2) Isotropicボクセル：最小スライス厚 $0.5 \mathrm{~mm} \times 4$ 列 により全身においてIsotropicを実現. サジタル，コロナル断面もア キシャル断面と同じ高精度の分解能での画像診断が実現できた。 3) S/Nの向上：MUSCOT再構成法によりS/Nが向上するため, 同じ画 質が低線量で得られる。これにより被曝線量の低隇が図れ，また同 一線量では画質の向上が図れた。 4) コンパクト性：ガントリサイズ はW1970×D890×H1760と非常にコンパクトであり，CTシステムを使 用したIVR-CTシステム, 術中CTシステム, 車載CTシステムなどに 適している.

\section{5 患者被曝管理用線量計の開発}

トーレック(株) 臼杵辰己

【目的】X線による診断時に患者(被検者)に照射されるX線の線量を明 らかにし，被曝管理のための基礎デー夕を収集する。

【概要】1) 本器は, 従来から一部で使用されてきた面積(照射)線量計 に，面積に依存しない(照射)線量計を組み合わせたもので，照射線 量と面積照射線量が同時に測定できる。これにより，「線量」の管理 が行なえるようになった。また，「面積線量」の意味の曖昧さも解消 できた. 2) 検出器 (電離箱)の電極には, PETフィルム上に透明導伝
膜をスパッタリング形成したものを使用し，光照射野を阻害するこ とがない．3)測定部には線量抢よび面積線量が常に表示され，被曝 量のモニタができる，表示值は，RS-232Cインターフェイスを経由 してコンピュータに取り込める.

【結論】従来型の面積線量竐ではできなかった「線量」の測定ができる ようになり，線量と面積の雨方を管理するというICRPの勧告に沿っ た被曝管理ができるようになった。

146 PLATOによるinverse治療計画(PLATO-ITP) (株)千代田テクノル・医療機器事業部医療技術 $\mathrm{Gr}$ 原健作 天野賢二，四方田章裕，都丸禎三

【はじめに】PLATO (planning, treatment, optimization)は, オランダ Nucletron社が開発したCTイメージをベースにした総合放射線治療計 画装置システムで, brachytherapy, external beam therapy, DVHなど による治療計画の評価システムなどから構成され, 米国, FDAの正 式許可を得た製品です。このうち external beam therapyシステム PLATO-RTSの付属モジュールであるPLATO-ITPによるinverse治療計 画法について紹介する。

【inverse治療計画とIMRT】intensity modulated radiation therapy (IMRT) を実行するために必須条件は，最適な治療計画を準備するシステ ム, inverse治療計画を備えることである.PLATO-ITPシステムで は，ドイッ，ハイデルベルグの国立癌研究所 Bortfeldらが開発した 勾配法を用いたinverse治療計画法を提供する。これは，各ターゲッ トボリュウム内の計算値とDVH最小, 最大制限線量の差を 2 乗しぺ ナルティ值を加える. そして計算值の前回との相違が基準值以下と なるまで勾配法による強度マトリクスの最適化が繰り返される。こ のBortfeldらの勾配法は計算速度が高速Simulated Annealing 法を用い た推計学的方法と比較すると，2オーダ早くなっている．最適化さ れた強度分布は，Steinらにより開発されたシーケンサーにより，ダ イナミックMLC法またはstep-and-shoot法による照射方法に最適化さ れる。

【今後の課題と将来展望】1)線量分布計算の高速化 2)さらなる高精 度化 3)多くのモダリティ画像の高精度高速処理

147 移動形血管造影システム Sirius Power/C

（株）日立メディコ・大阪工場設計部 和田＼cjkstart裕

検查範囲の拡大，操作性の飛躍的な向上を実現したIVR対応の移 動形血管造影システム「Sirius Power/C」について，おもな特長を紹介 する。

【1. 高画質】従来の移動形X線テレビ装置はX線出力が小さく，腹部 の血管造影検査などは困難であったが，Sirius Power/Cでは，X線出 力を大幅に向上させることにより，あらゆる部位の血管造影検査を 可能にした．また，受像部のX線カメラには，100万画素のCCDカメ ラを搭載し，映像を $1,024 \times 1,024$ マトリクスのデイジタル処理・表示 することにより，高精細でコントラストの良い画像を提供できる。 【2. 迅速・軽快な操作性】頭部や腹部の血管造影検査を行う時, 力 テーテルの先端を追従しやすいように，Cアームが横方向にスライ ド移動するので，医師が希望する箇所にすばやくポジショニングが でき, 検査時間の短縮と透視X線被曝の低減が可能である。また, 透視・撮影はフットスイッチを踏むだけで行え, ワンマン操作が可 能である，制御部とX線発生部を接続するケーブルはすべて内蔵さ れて抢り，ケーブルが患者や滅菌処理した検査用具に触れる心配が なく，ふところの深いCアームとの組み合わせで広い清潔空間を確 保でき，操作性を著しく向上している.

【3. 頭腹部IVRに対応できる画像処理機能】高速ディジタル画像処理 装置を内蔵することにより，リアルタイムDSA・ロードマッピン グ・自動ループ再生など, IVRに必要なあらゆる画像処理機能を標 